\title{
ŚLEPA PLAMA SYSTEMU
}

Michał Kaczmarczyk

Uniwersytet Gdański

\section{/// Krzysztof C. Matuszek. Systemy wojene. Wspótczesne wojny w per- spektywie teorii Niklasa Luhmanna}

Historia teorii socjologicznej XX w. zdaje się sugerować, że między różnymi jej nurtami istnieje niepisany podział ról. Tradycyjnie przyjęło się sądzić, że dla nurtów interpretatywnych zarezerwowane sa takie tematy, jak rodzina, społeczna dynamika emocji, procesy w małych grupach społecznych; dla funkcjonalizmu - analiza ruchów społecznych czy społeczny podział pracy, a dla teorii konfliktu - podziały klasowe i protesty polityczne. Na pierwszy rzut oka można by sądzić, że wynika to z faktu, iż odpowiednio do swych nazw wskazane teorie zbudowane sa na założeniach przypisujących kluczową rolę porządkowi społecznemu (funkcjonalizm), konfliktowi (teorie konfliktu) lub interakcji (nurty interpretatywne). Jest to jednak mylne przekonanie, jakkolwiek rozpowszechnione i faktycznie wpływające na badania socjologiczne. W istocie klasyczny funkcjonalizm nie jest wcale teoria porządku w tym sensie, że go zakłada. Przeciwnie, zakłada on konflikt i, badając jego mechanizmy, ukazuje, w jaki sposób wyłania się porządek. Podobnie teoria konfliktu zakłada istnienie porządków społecznych i różnych form legitymizacji uprzednich wobec mobilizacji grup interesów i koalicji politycznych. Dopiero na tym tle stara się wyjaśnić zmianę społeczną. Nie inaczej nurty interpretatywne, jakkolwiek zajmują się tym, co dzieje się między ludźmi $\mathrm{w}$ ich codziennych kontaktach, to $\mathrm{w}$ istocie zakładają uwarunkowania strukturalne jako swoiste ramy interpretacyjne. Najjaskrawiej jest to widoczne w podejściu Erwinga Goffmana.

Szczególna pozycję zajmuje na tym tle Niklas Luhmann, który zakłada nie tylko konflikt, ale więcej - przygodność i złożoność, będące koniecznym warunkiem ukształtowania się wysoce złożonych form porządku; nieprawdopodobieństwo będące warunkiem jakiegokolwiek (zawsze społecznie konstruowanego) prawdopodobieństwa. Teoria Luhmanna 
jest więc przeniknięta przekonaniem o swoistej arbitralności świata i życia, dystansuje się od wszystkiego, ponieważ wszystko jest jednakowo niepewne i względne jako konstrukcja społeczna. Mimo tak silnego akcentowania braku fundamentów, na jakich mogliby się oprzeć filozofowie, socjologowie czy sami działający, mając często nadzieję na odkrycie sensu moralności czy człowieczeństwa, Luhmann bardzo niewiele pisze o sytuacjach życiowych, które ów brak fundamentów najjaskrawiej ujawniaja - w tym przede wszystkim nie pisze o wojnie. Można wręcz sądzić, że jest to temat wyparty z jego rozważań i doszukiwać się biograficznych źródeł tego faktu (Joas, Knobl 2009). Można jednak również spróbować uzupełnić teorię systemów społecznych o pominięty w niej temat lub zastanowić się, jakie są konsekwencje teorii Luhmanna dla różnych nurtów badań nad wojną. Zadania tego bardzo kompetentnie podjął się ostatnio Krzysztof Matuszek w książce Systemy wojenne. Wspótczesne wojny w perspektywie teorii Niklasa Lubmanna. Jest to kolejna z serii książek, które ukazały się w ostatnich latach w Polsce na temat teorii Luhmanna i wyróżnia się wśród nich próbą oryginalnego rozwinięcia dzieła autora Systemón społecznych. Stoi ona przy tym na wysokim poziomie, zbliżając się pod tym względem do obszernego i niezwykle kompetentnego wykładu Luhmannowskiej teorii prawa autorstwa Jana Winczorka (2009). Książka Winczorka jest wzorem solidnej obrony teorii przed możliwymi argumentami krytycznymi i wskazaniem jej różnorodnych zastosowań, podczas gdy praca Matuszka jest odważnym, pomysłowym, choć też ryzykownym wyjściem poza propozycje autora Systemón spotecznych.

Warto podkreślić, że książki Systemy wojenne nie można odczytywać ani jako obrony teorii socjologicznej Luhmanna, ani jako próby jej krytyki. Intencją autora było raczej „,uzupełnienie” konstrukcji teoretycznej stworzonej przez niemieckiego socjologa bądź ewentualnie wskazanie, w jaki sposób może ona zostać skorygowana, jeśli ma obejmować dodatkowy fenomen empiryczny, jakim jest współczesna wojna. Tym samym Matuszek wpisuje swą książkę w dość powszechną tendencję w literaturze socjologicznej, polegająca na zapożyczeniu tez teoretycznych od określonego autora i przyjęciu ich jako założeń w analizie konkretnego wycinka rzeczywistości. W ramach tego podejścia, niezależnie od przyjętych metod badawczych, zawierza się określonej szkole teoretycznej, zawartej w niej wizji świata, założeniom ontologicznym, schematom pojęciowym, a niekiedy wyjaśnieniom. Wkład autora polega wtedy na poszerzeniu schematu, radykalizacji jego znaczenia bądź poszerzeniu mocy eksplanacyjnej teorii. Można się zastanawiać, czy takie podejście w ogóle 
jest słuszne i użyteczne, skoro raczej zawęża niż poszerza perspektywę poznawcza, ogranicza pole dialogu między teoriami przez wstępną selekcję. Już na tym etapie oceny przedsięwzięcia Matuszka należałoby zapytać, czy nie lepiej byłoby wybrać inną strategię badawcza, polegająca na porównaniu różnych koncepcji wojny i rozważeniu ich własnych założeń w świetle ewolucji wiedzy historycznej. Można się również obawiać, że książka wzbudzi zainteresowanie głównie wśród osób, które już fascynuja się Luhmannem, a nieco odstraszy tych, którzy chcieliby o wojnie poczytać w bardziej przystępnym języku i uzyskać szersze horyzonty teoretyczne.

Uzupełnianie czy korygowanie teorii, z którą autor się identyfikuje, ma większe szanse powodzenia, gdy nie traktuje wyjściowej teorii jako zamkniętego układu odniesienia. Jeśli tak czyni, to postawione zadanie jest szczególnie trudne do zrealizowania w przypadku teorii Luhmanna, która słynie ze spójności wewnętrznej. Nawet jej krytycy rzadko potrafia sformułować zarzuty wykazujące sprzeczności w rozumowaniach autora Systemów społecznych i odnoszą się do całej jego twórczości, krytykując jej zbytnią hermetyczność i empiryczną nieadekwatność bądź nawet niefalsyfikowalność. Matuszek zastanawia się tymczasem nad możliwościa dodania do palety systemów społecznych omawianych przez Luhmanna systemu wojennego, który miałby być zamknięty operacyjnie i wyodrębniać się przez własny kod oraz funkcję społeczną. Jednak jeśli autor myślał o uzupełnianiu teorii swego guru, to zadanie takie ma sens tylko pod warunkiem, że sam Luhmann na temat wojny nie pisał albo to, co pisał, nie spełniało kryteriów logicznej spójności bądź empirycznej adekwatności albo też że nie można takiej koncepcji z jego myśli wyinterpretować. Tymczasem uważny czytelnik prac Luhmanna zorientuje się, że niemiecki myśliciel znajduje $\mathrm{w}$ swych pracach miejsce dla tej tematyki, ale głównie pod hasłami konfliktu i polityki. Wbrew pozorom, jego radykalny funkcjonalizm nie pociągał za sobą lekceważenia tematu wrogiej konfrontacji, a wręcz przeciwnie, pozwolił wprowadzić tematykę konfliktu czy sprzeczności interesów do rozważań o podstawowych procesach tworzenia się systemów społecznych w warunkach podwójnej kontyngencji. Matuszek nie pomija tego faktu - ten właśnie wątek wręcz najbardziej go fascynuje - jednak dokonane wybory teoretyczne każą postawić pod znakiem zapytania sensowność korekty teorii systemów społecznych.

Zacznijmy od tego, że według Luhmanna konflikt stanowi uniwersalne zjawisko występujące wszędzie tam, gdzie komunikuje się sprzeczność, gdzie staje się ona zalążkiem tworzenia własnej struktury konfliktu. W uproszczonym sensie, konflikt polega na mówieniu „nie”, którego 
funkcją jest utrzymanie autopojezy systemu. Występuje we wszystkich rodzajach systemów, na różnych poziomach komunikowania się: interakcyjnym, organizacyjnym i ogólnospołecznym. Ta wszechobecność konfliktu nie zmienia jego zasadniczej natury, jaką jest negatywna podwójna kontyngencja przywracająca system do życia niezależnie od jego struktur. Fakt, że komunikuje się sprzeczności w sposób uzasadniony czy w zamiarze integracji, w niczym nie zmienia tej zasadniczo radykalnej, odnawiającej siły konfliktu. Wprawdzie buduje on własne struktury, ale nigdy nie opuszcza systemu, w którym się rodzi. Matuszek expressis verbis zrywa z tą koncepcją ${ }^{1}$, aby wprowadzić do teorii systemy wojenne jako takie, które mają do dyspozycji „wszystkie warunkujące je struktury”. Odwracając się w ten sposób od efemerycznych, ale też - patrząc en bloc - być może najistotniejszych społecznie form konfliktu, Matuszek traci z pola widzenia ich funkcję systemów immunologicznych i w najobszerniejszym, trzecim rozdziale pracy daremnie szuka funkcji wojny, traktując ją jako „odpady” procesów różnicowania funkcjonalnego ${ }^{2}$. Co więcej, zmuszony jest odróżniać swoje „systemy wojenne” od typowych, potocznie nazywanych wojnami, działań polityczno-wojskowych nowoczesnych państw zachodnich ${ }^{3}$.

Druga konsekwencją wyodrębnienia przez Matuszka systemów wojennych jest oderwanie ich od ewolucji innych systemów i potraktowanie jako systemów komunikacyjnych będących nie tylko, jak pisał Luhmann, „systemami pasożytniczymi”, ale wręcz jako systemów atakujących struktury społeczne, niezdolnych do synchronizacji. Tym samym autor recenzowanej pracy traci z pola widzenia integracyjną funkcję konfliktów, aby później poszukiwać jej, odwołując się do dziejów XX-wiecznego funkcjonalizmu i związku pojęcia funkcji $\mathrm{z}$ adaptacją do nowych sytuacji problemowych w otoczeniu społeczeństwa. Luhmann tymczasem, mimo swego krytycyzmu wobec wszelkich teorii (w tym teorii konfliktu), które podzielają marzenie o społeczeństwie wolnym od konfliktów, właśnie dzięki niezależnemu od warunków strukturalnych zdefiniowaniu tego zjawiska może wskazać różne (w tym najbardziej ogólne) formy integracji, do jakich prowadzi konflikt, gdy odniesiemy go do społeczeństwa jako systemu. Pisze: „Konflikty osiagaja jednocześnie to, co zwykle bezskutecznie próbuje się osiagnąć za pomoca apeli o lojalność - wysoką efektywność więzi w stosunku między interpenetracją a struktura. Dotyczy to nie tylko

\footnotetext{
${ }^{1}$ Matuszek, Krzysztof C. Systemy wojenne. Wspótczesne wojny w perspektywie teorii Niklasa Lubmanna. Kraków: Wydawnictwo WAM, 2010, s. 28 przyp.

${ }^{2}$ Tamże, s. 117.

${ }^{3}$ Tamże, s. 119 i nast.
} 
solidaryzacji w ramach spierających się partii, lecz także właśnie samej wrogości. Ten, kto traci swego wroga, odczuwać będzie swoistą pustkę - brakować mu będzie motywów działania, do których sam siebie zobowiązał. Będzie mu brakować możliwości układania wielu okazjonalnych przypadków w jedną historię, skoro odpadł konflikt jako względnie trwała linia identyfikacji. W obszarze systemów społecznych mało jest innych możliwości tak daleko idącego generowania jedności generalizacji i zobowiązania do działania z udziałem motywów wewnętrznych" (Luhmann 2007: 365). Matuszek odchodzi od analizowania konfliktu w sposób zaproponowany tu przez Luhmanna, ale zarazem zachować chce tezę o komunikacyjnym (a nie np. działaniowym) charakterze systemu wojennego. Przez to systemy te obejmują w jego ujęciu jedynie jedną stronę konfliktu, są to systemy wykluczające nie tylko w sensie operacyjnej zamkniętości, ale także w sensie wyłączania komunikacji wroga. Nie ulega wątpliwości, empirycznie rzecz biorąc, że wojny niejednokrotnie oznaczaja rezygnację z komunikacji i eskalacje przemocy, jednak dla Matuszka nie jest to pretekst do krytyki teorii Luhmanna, która jest tylko i wyłącznie teorią komunikacji, a przez to nie radzi sobie $z$ wieloma ważnymi dla społeczeństwa zjawiskami niekomunikacyjnymi, jak przemoc czy emocje. Fakt ten jest raczej dla autora recenzowanej książki zachęta do rezygnacji z analizowania samych systemów konfliktu na rzecz systemów powstających na bazie konfliktu w społeczeństwach prowadzących wojnę. Przez to powstaje kolejna wątpliwość: czy mianowicie stosowanego przez Matuszka pojęcia systemów wojennych nie można bez uszczerbku logicznego i empirycznego zastąić Luhmannowskim pojęciem polityki? Notabene, sam Luhmann niejednokrotnie pisze o kodzie wróg/przyjaciel właśnie jako o re-entry kodu systemu polityki. Wojna byłaby w takim ujęciu kontynuacja polityki lub, mówiąc bardziej precyzyjnie, jej szczególnym środkiem, podporządkowanym wszakże regułom efektywności.

Istnieje jednak jeszcze inna możliwość, o której Matuszek pisze raczej marginalnie, a mianowicie powiązanie wojny z systemem prawa. Ten związek ma już inną naturę, prawo nie jest bowiem wstępem do wojny ani wojna nie jest szczególnym rodzajem prawa. Chodzi raczej o to, że wojna szczególnie łatwo poddaje się regulacji prawnej, jest rodzajem pretekstu do stosowania prawa, rozszerzania jego zakresu, tworzenia nowych regul kolizyjnych i przekraczania barier związanych z pojęciem suwerenności. Wymowa teorii Luhmanna każe sądzić, że wojna jest rodzajem przeżytku stającego na drodze funkcjonalnego zróżnicowania i wiąże się z ciagle jeszcze powszechnie uznawaną i stosowaną fikcją suwerenności. Tym 
samym wojna stanowi materię pozwalająca prawu tworzyć własną wewnętrzną złożoność, wykraczając poza opłotki systemów normatywnych budowanych na potrzeby konfliktu. Tak jak w początkach historii prawa społeczeństw państwowych prawo umożliwiało konflikty, aby wykorzystać je do tworzenia własnej złożoności, tak dzisiaj jego tworzywem w wymiarze międzynarodowym są wojny. Jednocześnie na skutek tego procesu dochodzi do sprzężenia strukturalnego prawa i polityki przekraczającej granice państw. Jednak nakreślona właśnie obserwacja ma swoje głębsze podstawy teoretyczne. Trzeba wszak zauważyć, że prawo jest w teorii Luhmanna nie tylko systemem społecznym - jest ono także struktura zgeneralizowanych oczekiwań, a krócej: strukturą społeczną jako taką. Wojnę można traktować jako podstawowe zagrożenie dla tak pojętej struktury - dla sieci wzajemnych oczekiwań - ponieważ odbiera ona nawet fundamentalną pewność życia, własności czy nietykalności. Nie bez powodu w tym właśnie kontekście i we fragmencie Systemów społecznych poświęconym strukturze społecznej pisze Luhmann o pokoju, a więc przeciwieństwie wojny: „[...] jeśli oczekiwania noszą w sobie ciężar struktury, to są też mniej lub bardziej narażone na rozczarowania. Możliwość spotkania się z rozczarowaniem jest więc problemem samego oczekiwania, problemem jego pewności i stabilności. Oczekiwanie musi być w stanie absorbować niebezpieczeństwo rozczarowania. Jeśli to się nie udaje, to możliwość rozczarowania oddziałuje symboliczno-destrukcyjnie na samo oczekiwanie. Określone konteksty oczekiwania są bardziej wrażliwe niż inne, wrażliwsze są na przykład oczekiwania życia czy dochodu. [...]. Ta okoliczność, polegająca na wysokiej strukturalnej wrażliwości na coś po prostu możliwego, symbolizowana jest przez pojęcie pokoju - pojęcie wymierzone przeciw strachowi, obejmujące dziś nie tylko oczekiwania życia, lecz właśnie również dochodów, czy wszelkiego rodzaju oczekiwania dobrobytu (zapewne przy założeniu, że wszelkiego rodzaju szkoda ma tendencję do czynienia ludzi agresywnymi). W tym sensie pokój jest warunkiem ukształtowania się struktury par excellence. Pod pojęciem pokoju rozumie się nie tylko pozytywny korelat negatywnej oceny określonych zdarzeń, lecz wartość, jaką ma dla budowy struktury unikanie tych zdarzeń. Gdyby trzeba było ich oczekiwać, to zbyt wiele byłoby niemożliwością" (2007: 311). Gdyby podążać za interpretacją Luhmanna lub przynajmniej starać się zachować jej ducha, należałoby uznać wojnę za zbiorcze pojęcie określające masę rozczarowań powyżej punktu krytycznego, po którego przekroczeniu struktura przestaje być możliwa, a oczekiwania tracą swój kontrfaktyczny charakter. W tym sensie wojna 
pozwala tylko na kognitywny styl oczekiwań, ale nie tak, jak system nauki, który sam kreuje oczekiwania, lecz w kontekstach wycofywania oczekiwań - wszędzie tam, gdzie nie można oczekiwać normatywnie, a więc tam, gdzie prawo się załamuje. Włączenie wojny do systemu prawa oznacza, że prawo jako system społeczny jest ukierunkowane na wojnę - opisuje ja jako obszar interwencji i mobilizuje do tego inne systemy.

Jak już wspomniałem, Matuszek zdaje się obawiać wykorzystania swych spostrzeżeń do bardziej zdecydowanego rozrachunku z dziełem Luhmanna, a tego właśnie byłoby można spodziewać się po jego książce, która odważnie wkracza na tereny dla niemieckiego socjologa niewygodne: opisuje kłopoty zróżnicowania funkcjonalnego, powolny marsz modernizacji i zawodność systemu polityki w rozwiązywaniu problemów społecznych. Wskazuje też na mechanizmy wzmacniające spiralę przemocy i systemowo wyjaśnia niezdolność stron konfliktów społecznych do dialogu. Jego rozważania nasuwaja pytanie, czy teoria Luhmanna wystarcza do wyjaśnienia sytuacji, w których komunikacja zostaje przerwana, a systemy ukształtowane w wyniku nowoczesnego różnicowania się społeczeństwa zapadaja się w wyniku pochłaniania zasobów systemów przez konflikty, a w ostateczności przez niepohamowaną eskalację przemocy. Ponadto, czy prace Luhmanna pozwalają na systematyzację różnych form konfliktu i dostrzeżenie ich kreatywnej roli w kształtowaniu struktur systemów? Wreszcie, czy Luhmannowska teoria komunikacji wystarcza do odpowiedzi na pytanie o mechanizmy ewolucji konfliktu, o kształtowanie się pokojowych strategii działania? Trzeba wszak zauważyć, że w XX w., oprócz rozwoju technik wojennych i wzrostu złożoności struktur służących do prowadzenia działań wojennych, mamy do czynienia z rosnącym znaczeniem technik pozbawionych przemocy (non-violent action), które częstokroć okazują się bardziej skuteczne i to właśnie ze względu na swój charakter komunikacyjny. Tego rodzaju zbiorowych form uczenia się nie trzeba szukać daleko - dostarcza ich choćby polski ruch „Solidarności”, który, opierając się na doświadczeniach własnych i pokoleń Polaków, wypracował strategię łącząca presję symboliczną z negocjacjami.

Aby opisać wymienione wyżej i inne zjawiska związane z rozwojem ruchów społecznych, nowymi formami prowadzenia wojen i ich regulacji, należało jednak raczej przyjrzeć się interpenetracji systemów niż wydzielać kolejny i poszukiwać specyficznych dla niego kodów i programów operacyjnych. Analiza skupiająca się na wzajemnych zależnościach między prawem, polityka, gospodarką oraz specyficznych dla nich mechanizmach eskalacji i regulacji konfliktów pozwoliłaby zapewne na wyjaśnienie 
ewolucji wojen od czasów znacznie wcześniejszych niż druga połowa XX w. i ich roli w wyodrębnianiu się systemów społecznych. Mogłaby też pomóc w przezwyciężeniu wad podejścia Luhmanna, które w zbyt małym stopniu pozwala na wyjaśnianie różnych form funkcjonalnego zróżnicowania i jego działaniowych uwarunkowań. Warto by było wreszcie zastanowić się, dlaczego wojna została tak dalece zmarginalizowana przez Luhmanna, choć wymagałoby to zapewne pracy bardziej biograficznej niż tylko teoretycznej. Czy temat ten nie był rodzajem ślepej plamy systemu teoretycznego niemieckiego socjologa, który na skutek powojennych doświadczeń pobytu w amerykańskim obozie jenieckim, przesiąknięty poczuciem niesprawiedliwości i arbitralności wyroków losu, postanowił oprzeć swą późniejszą refleksję na strategii naukowego dystansu, a przez to pozbawić ją wątków krytycznego zaangażowania? Wojna wydawać się mogła tematem bardzo niewygodnym, wymagałaby bowiem, być może, przekroczenia tej postawy, większego krytycyzmu wobec bieżących wydarzeń, ale również porzucenia nieprzejednanej wiary w systemy. $\mathrm{Na}$ te bardzo ogólne pytania i watpliwości nie znajdziemy odpowiedzi w książce Matuszka, choć samo podjęcie tematu wojny wydaje się znakomitym przyczynkiem do dalszych badań. Recenzowana książka nie pozostawia też watpliwości, że jej autor potrafi podjać oryginalną i ciekawą dla czytelnika refleksję nad peryferiami teorii Luhmanna. Pozostaje nam jedynie czekać na kolejną podobnie inspirującą publikację autora.

Bibliografia:

/// Joas, Hans, Knöbl, Wolfgang. 2009. Kriegsverdrängung. Frankfurt am Main: Suhrkamp.

/// Luhmann, Niklas. 2007. Systemy społecæne. Zarys ogólnej teorii. Kraków: NOMOS.

/// Matuszek, Krzysztof C. 2010. Systemy wojenne. Wspótczesne wojny w perspeketywie teorii Niklasa Lubmanna. Kraków: Wydawnictwo WAM.

/// Winczorek, Jan. 2009. Zaginiecie dwunastego wielbłada. O socjologicznej teorii prawa Niklasa Lubmanna. Warszawa: Liber. 